\title{
De-centering the Revolution: Class Composition in the Making and Defeat of the Bavarian Council Republic
}

\author{
Simon Schaupp \\ University of Basel, Faculty of Humanities and Social Sciences, Basel, Switzerland
}

\begin{abstract}
In November 1918, the labor movement of Bavaria, Germany, overthrew the monarchist government and, in April 1919, proclaimed a Bavarian Council Republic (BCR). This article analyzes the revolution and its defeat through the lens of class composition theory, thereby suggesting some revisions to the latter. The technical composition of the Bavarian working class fostered the concept of self-management, which lay at the heart of the councils as the organizational form of the revolution. However, it also nurtured authoritarian potentials, which were more in line with-counter revolutionary positions. The article suggests that class composition theory must be expanded by the notion of social composition, taking into account struggles over reproduction and consumption: Inflation, unemployment, food shortages, and disease led to a crisis in material reproduction, which in turn led large parts of the unemployed and of the women's movement to become radical revolutionaries. The article argues to conceptualize technical and social class composition to be in a dialectical relationship with political composition. It thus emphasizes the role of ideologies of anti-Semitism and anti-feminism, both within the counter-revolution and the revolution itself. While the combination of different struggles for emancipation contributed to the early successes of the revolution, their ideological division was as an important factor in its defeat.
\end{abstract}

\section{Introduction}

In November 1918, the labor movement of Bavaria, Germany, overthrew the Wittelsbach monarchy dynasty. Subsequently, in April 1919, a Socialist Bavarian Council Republic (BCR) ${ }^{1}$ was proclaimed. ${ }^{2}$ The historiography of the German November Revolution has largely focused on the ever-same "centers": In terms of space, this center is Berlin; in terms of agency, this is the male industrial proletariat. This article argues for a decentering of the November Revolution. In terms of space, not only did the BCR go much further than any of the revolutionary attempts in Berlin but it is also misleading to speak of a "Munich Council Republic,"3 because the Bavarian revolution was constituted by simultaneous uprisings all over the federal country. ${ }^{4}$ In terms of the agents of the revolution, the narrow focus on the male industrial proletariat limits the understanding of the more complex social composition of revolutionaries

\section{International Labor and Working-Class History}

No. 100, Fall 2021, pp. 1-21

(C) International Labor and Working-Class History, Inc., 2021. This is an Open Access article, distributed under the terms of the Creative Commons Attribution licence (http://creative commons.org/licenses/by/4.0/), which permits unrestricted re-use, distribution, and reproduction in any medium, provided the original work is properly cited.

doi:10.1017/S0147547920000149 
(and their adversaries). This article therefore argues to take into account the important roles that were played by women, by the unemployed, and by the peasantry all over Bavaria. While most of these factors have already been addressed in different studies, ${ }^{5}$ they have mostly taken the form of mutually excluding singular focus points. However, in laying out the complex dynamics that led to the revolutionary uprising and the subsequent pre-fascist backlash, a more integrated and theory-oriented framework is necessary. ${ }^{6}$

This article therefore applies the theoretical lens of class composition. This theory originated in the Italian Marxist current of operaismo ("workerism"). It argues that class must be understood as the relationship between the "technical composition" and the "political composition." Technical class composition refers to the particular ways in which production is organized. It asks which industries are dominant, which technologies and skills are used, and how workers collaborate. Political class composition refers to the workers' cultural and political expressions. It mostly focusses on workplace conflicts or political organization. ${ }^{7}$ One of the central texts that developed a historiographic notion of class composition is Sergio Bologna's study of the German council movement. ${ }^{8}$ By examining the BCR, the article at hand therefore "revisits" 9 this case in order to expand the notion of class composition. It thereby challenges Bologna's assumption that the material development of the German machine industry necessarily led to the council movement. By underlining the role of female workers, of the unemployed, and of the peasantry in the revolution, it argues for a re-assessment of the hypotheses of the vanguard role of the industrial proletariat. By emphasizing the effects of war-weariness, hunger, and disease, as well as the importance of anti-Semitism as an integrating counterrevolutionary ideology, it argues for a non-deterministic understanding of class composition. In doing so, it builds on the notion of social composition as an important but underdeveloped factor in class composition. This is to point out how consumption and reproduction form part of the material basis of political class composition. It involves factors like the gendered division of labor, the purchasing power of wages, housing, patterns of migration, and community infrastructure. ${ }^{10}$

The first section analyzes the technical composition of the proletarianized ${ }^{11}$ in Bavaria. It argues that the leap in industrialization before and during World War I did in fact play a major role for the formation of the council movement. It adds however the importance of the category of space in analyzing the technical class composition so as to be able to understand the role of the peasantry and issues in the geographical dispersion of the movement. The second section analyzes the social class composition by emphasizing the role of unemployment and material misery that greatly contributed to the anger of the Bavarian population at the end of the war. It also sheds light on the special position of women, both in the war economy and in the prelude to the revolution. The third section analyzes the political class composition in sketching the conflict between council democracy and parliamentarianism within the labor movement, which was far from being predetermined by technical composition. It also accentuates the role of anti-Semitism and anti-feminism as integrating ideological factors in the 
counter-revolution. Analytically, the article concludes that class, gender, space, and race are central categories for understanding both the rise and the defeat of the BCR. The initial success of the revolution was largely owed to a combination of struggles around these categories. Its later defeat, in turn, was largely due to their division.

\section{Technical composition}

Industrial workers, soldiers, peasants, the unemployed; in short, the proletarianized have been the agents of the council movement. Additionally, writers played an important role as organic intellectuals. ${ }^{12}$ However, their role has been highly overstated as can be seen in publications with titles like Dreamers: When the poets took power. ${ }^{13}$ This overstatement can be traced back to the counter-revolutionary propaganda of the time, which repeatedly tried to reduce the revolutionaries to "writers, alien to Bavarian land and being."14

Like in other historical instances, the revolutionary movement was especially strong where large industrial companies congregated workers on a massive scale. Before and during World War I, there was a leap in industrialization in Bavaria. In the important industrial cities of Augsburg, Furth, Wurzburg, Nuremberg, Hof, Bayreuth, and Erlangen the proportion of industrial and craft workers ranged between 67 and 70 percent. ${ }^{15}$ This was mainly owed to the decision to make Bavaria the center of the armament industry by giving major contracts to local companies and setting up new armament factories. Official contemporary statistics claim that in 1917 about 90 percent of the Bavarian industrial workers were employed directly or indirectly in the armament industry. ${ }^{16}$ Bologna convincingly demonstrates that the mechanical industries in Germany had not yet been affected by Ford's and Taylor's innovations of the assembly line and scientific management. Therefore, the industrial workers had high professional values and were naturally inclined to stress their function as producers. This, he argues, determined the political form of council democracy and self-management, which lay at the center of the Bavarian revolution:

The concept of self-management pictured the worker as an autonomous producer, and the factory's labor-power as self-sufficient. It only saw the relation between the workers and individual employers, or companies, and it distrusted "politics" in its broad sense, i.e., the relationship between organization and power, party and revolution. ${ }^{17}$

However, the reference to the "labor aristocracy" of the industrial workers is not sufficient to analyze the technical class composition, as it cannot explain the simultaneous uprisings that occurred all over the country. During the war, the majority of the proletarianized males were soldiers. From the mutiny of the sailors in Kiel, to the rebellion of the troops on the southern borders of Germany, soldiers were the first to start the revolution. During the mass demonstration in Munich on November 7, 1918, which lead to the flight of King Ludwig 
III, the vast majority of local soldiers joined the uprising. The same happened at the posts of other troops in Bavaria, not only in the cities but also in the countryside. ${ }^{18}$ Most soldiers were weary of the war, and revolutionary agitation spread quickly. This was largely due to the fact that, like industrial workers, soldiers worked in huge mass organizations, in which agitation and revolutionary organization were reasonably easy. This made the quick set up of soldier councils after the revolution possible.

Most of the historiography of the German November Revolution strongly focusses on the industrial centers. Bologna claims that because mechanical industries were mainly located in Wurttemberg, Saxony, and Berlin, this was where the council movement was strongest. ${ }^{19}$ Other historiography focuses solely on Berlin. ${ }^{20}$ Klikauer even claims: "What happened in Berlin was mirrored throughout Germany." ${ }^{21}$ This seems rather odd, considering the fact that the revolution succeeded only in Bavaria in actually putting council rule into effect. But also with regard to the historiography of the BCR itself, some spatial decentering seems necessary. The name "Munich Council Republic" has become common for the Bavarian revolution. ${ }^{22}$ The same happened with other phases of German history, named after the current capital. In the case of the Bavarian Council Republic, however, the impression is conveyed that the revolution actually took place only in Munich. In fact, Munich was indisputably the center of revolutionary activity. Nevertheless, while the revolutionary threads converged in Munich, the BCR extended over nearly the whole of Bavaria. There were council structures down to the smallest provincial villages. ${ }^{23}$

Already on the first day after the fall of the monarchy, it was not only large Bavarian cities that declared their support for the socialist "people's state." Enthusiastic telegrams also arrived from thirty-two smaller cities. In the following days, the council movement was spreading even to the smallest towns in all governmental districts - without outside intervention, but through spontaneous revolutionary actions of workers and local socialist parties and groups. Hardly any of these towns simply copied the Munich declarations. After the military defeat of the council movement in Munich in the first days of May 1919, the importance of the provincial towns for the revolution became clear once again. The remnants of the Bavarian Red Army withdrew to Rosenheim and Kolbermoor, southeast of the state capital, where there was a strong revolutionary base. There, they fought for several more days before being defeated. ${ }^{24}$ Thus, the radicalization of the council movement not only came from the political center of Munich but was a dispersed process in all of Bavaria.

As about half of the Bavarian population worked in the agrarian sector, ${ }^{25}$ it is important to understand the role of the peasantry. The major farmer's association, the Bayerischer Bauernbund, (BBB, Bavarian Farmer's Union) was dominated by progressive Social Democrats. From the beginning, it took part in organizing the uprising. After the monarchy was defeated, farmer's councils emerged from this organization. ${ }^{26}$ However, the peasantry was spread out over long distances, which made communication and organization difficult. This was also due to the fact that the communication infrastructure was unreliable. 
Thus, communication between the cities and the agrarian hinterland was disrupted quite early after the revolution. This made the peasantry vulnerable to counter-revolutionary propaganda. Therefore, farmers in the Upper Palatinate and the Ries imposed a food blockade against the revolutionary cities in southern Bavaria. Resulting in a famine in Munich, this significantly weakened the council government. Later, many of the members of the counter-revolutionary Freikorps (volunteer corps) were also recruited among the peasantry. ${ }^{27}$

To sum it up, the technical composition of industrial work did lay the basis for the revolutionary organizations. However, the specifics of military organizations also contributed to the strength and the quick spread of the movement. Additionally, it is important to note that the BCR was not spatially limited to Munich, but extended over nearly the whole of Bavaria. Despite granting the revolution a mass base, this geographical dispersion was also a central factor for its suppression, not only in terms of military strategy but also in terms of political communication. In this, the role of the peasantry shifted from largely revolutionary to largely counter-revolutionary. Sensitivity in terms of space is therefore central to understanding the technical class composition as it constitutes a central factor the in dynamics of power. ${ }^{28}$

\section{Social composition}

In a short but insightful text, the editors of Notes from Below ${ }^{29}$ argue that the concept of technical class composition can only grasp one part of the process of class formation. Following Marx, from the perspective of the worker, wage labor means the commodity labor power is sold for money, which is used to buy the means of subsistence, which in turn reproduce labor power. ${ }^{30}$ The concept of technical composition, however, only encompasses the transformation of commodity into money (labor process), while money to commodity (reproduction) is left out. Consumption and reproduction must therefore be defined as additional arenas of struggle beyond production, amounting to social class composition. This fills two gaps: First, it transcends the limitation of the concept of class composition to wage laborers by accounting for all the proletarianized, including the unemployed and workers not directly involved in producing the capitalist form of value. Second, it helps to understand "the specific material organization of workers into a class society through the social relations of consumption and reproduction." ${ }^{31}$ Both of these aspects prove to be essential for understanding the processes that led to the Bavarian revolution.

3.1 The crisis in reproduction. To finance the war, in 1914, the German Reich government had taken on heavy debts and abolished the Reichsbank's obligation to exchange bank notes into gold. This lead to grave inflation. By the end of the war, the Mark had already officially lost more than half of its purchasing power both internally and externally. On the black market, the inflation index was much higher. ${ }^{32}$ At the same time, the war led to shortages in consumer goods, especially food, and therefore to a steep rise in prices. With this decrease 
in purchasing power, capital lost the wage as its central tool for the production of consent. The resulting material misery was a central factor in the radicalization of big parts of the proletarianized. ${ }^{33}$ At least since the so-called "turnip winter" of 1916/17, famine had spread throughout Europe. Much of the available food was reserved for boarding the armies at the frontline, leaving little to the urban population. By the end of 1918, the Ministry of Health registered 763,000 deaths in the German Reich due to hunger and malnutrition. ${ }^{34}$

During wartime, the pandemic called "the Spanish flu" added to the effect of war-weariness that, turning into a widespread frustration, brought on a climate favorable to an uprising. In Munich alone, between 25,000 and 30,000 people were infected. Even the schools were temporarily closed because of the flu that called about 300,000 deaths nationwide. Due to the war, the disease spread rapidly across the globe. Worldwide, between 25 and 50 million people succumbed to the pandemic. ${ }^{35}$

This crisis in material reproduction was deepened at the end of the war by rising rates of unemployment: After the stop of arms production, the percentage of industrial employment in Bavaria shrunk to 34 percent (the German average was 46 percent). ${ }^{36}$ By far not all of the sacked armament workers and very few of the demobilized soldiers were able to find other work. Thus, in February 1919, 1.1 million were unemployed in Bavaria and the aggregated income lay significantly below the national average. ${ }^{37}$ This situation contributed to the radicalization of large parts of the Bavarian population. Especially the unemployed played a major role in the radicalization of the labor movement. From 1916 onwards, they were at the core of frequent food riots, which then turned into antiwar demonstrations. In the bigger cities of Bavaria, the monarchist government regularly sent soldiers to crush these riots. Even the final proclamation of the Council Republic in April 1919 was enforced by regular mass demonstrations of the unemployed. ${ }^{38}$

Thus, the severe crisis in material reproduction finally drove out the enthusiasm for war from the proletarianized of Europe and helped to spark revolutionary sentiments. ${ }^{39}$ However, it also laid the basis for counter-revolutionary mobilization. The far-right counter-revolutionary militias (Freikorps) were financed by generous donations, which doubled a fighter's pay, compared to the money fighters of the Red Army received. This ultimately made the decision for many starving men to join the Freikorps. In addition, the Freikorps paid a bonus of five marks for each "stand-by day" and ten marks for each "day of battle." There also were bonuses for each prisoner made. This commission system also contributed to the brutality of the counter revolutionary troops: Shooting at unarmed workers or indiscriminately taking prisoners guaranteed provisions without risk. Nevertheless, as they continuously registered desertions, the generals considered most of their troops unreliable. Thus, a secret order assigned strict quartering and frequent change of quarters in the occupied cities in order to avoid the "destructive effect of contact with the working-class population." 40 
3.2 Women revolutionaries. Women were affected by the material misery even more than men. At the end of the war, unemployed women and girls, homemakers and mothers were summoned to the so-called "labor front." The ban on women to work in the mining industry was lifted and the proportion of female workers in the armament industry increased strongly. On average, their salary was half of what their male colleagues earned. Additionally, after long hours in the factory the reproductive household work still was to be done. Some of the female armament workers carried out small acts of sabotage to protest the war. They filled too little powder into the grenades or inserted malfunctioning detonators. Some of them also distributed rebellious leaflets. At the same time, several women's peace demonstrations took place in Munich. They were to become crucial in revolutionary agitation in January $1918 .{ }^{41}$

In fact, women's groups were quite powerful and proved to be an important institution of the labor movement. The self-organization of women disturbed the perceived natural order of German postwar society. Politicians soon found foreign agents responsible for the seemingly unusual behavior of women. A report by the Bavarian Ministry of War states: "The organization of the female part of the population has made extraordinary progress during the last decade, and the war has only served to encourage the leaders of this movement to intensify their efforts." Some of these women, the ministry claims, were "under international influence and rally under the motto 'war on war'. They see the World War as proof for the bankruptcy of the current 'culture of man'.,42

On December 16, 1918, the women's platform Bund Sozialistischer Frauen (BSF, Federation of Socialist Women) was founded in Munich. "It is the first socialist women's organization, which is independent of the socialist male parties and factions," it said in its magazine Die Frau im Staat. ${ }^{43}$ The BSF pressured the Ministry of Social Welfare to install a special women's rights unit. Under the leadership of the independent Socialist Gertrude Baer, it took up its work in the old Wittelsbach Palais on February 11, 1919. The unit focused on the working conditions of women who faced mass dismissals due to the numerous male returnees from the front. Baer repeatedly conflicted with her more conservative supervisor, the Minister of Social Affairs, Hans Unterleitner. Thus, the unit was dissolved again after one month.

Due to the collaboration of the women's and worker's movements, the revolution brought about several important feminist successes. For the first time in the history of Germany, the Bavarian revolution granted women the right to vote and to work as judges. ${ }^{44}$ As a measure against counterrevolutionary activities, a revolutionary tribunal was set up in the Council Republic. So far, women had been allowed to study law but not to practice it. The Bavarian Revolutionary Tribunal was the first German court in which women worked as judges. In addition, the women's rights officer at the Ministry of Social Welfare sought an equal representation of women in court for offenses committed by women or in which women appeared as plaintiffs.

Women also formed their own labor unions. At their pressure, the Gesinderecht was revoked, which had given homeowners authority over the 
entire life of their domestic workers. However, the new regulations did not go far enough for the BSF, as it also radically questioned the status of maids and female housework. In an article, Lida Gustava Heymann, a leader of the BSF, wrote that it is generally a humiliation for a human being to be a servant. She called for "central households" with apartments for several families, where food, heating, laundry, and the like were to be organized collectively. These households, she argued, should also include nurseries, kindergartens, and daycare centers. Housework should be carried out by domestic workers, but with regular working hours and for a good wage. In addition, state-of-the-art technology was to be used, such as "vacuum cleaners for cleaning the dwellings." She called on domestic workers to refuse to serve in individual households from now on. "The capitalist state has run bankrupt," she concludes. "We are taking huge steps towards socialization." 45

The female revolutionary Toni Sender argued that "The councils can only become an expression of the mass will, which they should be, if the right to participation and co-determination does not remain a dead letter for a whole half of the proletariat."46 Therefore, Sender said, there must be separate councils in which women are adequately represented and their work is taken seriously. Sender's proposal was to "advocate the creation of an electoral association of proletarian housewives with district-by-district subdivision." 47 Similarly, the BSF also demanded the establishment of women's councils at a meeting of the general council congress in Munich. However, the request was supported only by the delegates of the radical Left, so there was no formal representation of women.

To sum it up, women and unemployed men played an important role in advancing the council movement. Bologna's reduction of the revolutionary subject to industrial workers therefore seems inadequate. Especially in the beginning of the revolution, parts of the women's and the labor movement were inherently connected, which lead to some important successes of the two. In the later course of events, however, they partly took conflicting positions, as will be demonstrated below.

\section{Political composition}

Early class composition theory postulates a direct deterministic relationship between the technical composition (the organization of labor power into a working class) and political composition (the self-organization of the working class into a force for class struggle). Bologna's deduction of the necessity of the council movement as the political form of struggle from the technical class composition is a prime example for this approach. It was explicitly developed against theories that give primacy to the notion of class consciousness. ${ }^{48}$ Notes from Below follows this early deterministic approach when claiming: "The transition between technical/social and political composition occurs as a leap that defines the working-class political viewpoint." 49 In his later works, however, Bologna revised his deterministic view, stating that political composition went 
beyond questions of organization and could not simply be deduced from technical composition as it is constituted by

the sum and interweaving of the forms of culture and of behaviours of both the mass worker and all the strata subsumed to capital. [...] Machinery, the organisation of labour, transmute and bring to light these cultural pasts; mass subjectivity appropriates them and translates them into struggle, refusal of labour, organisation. Political class composition is above all the result, the end point of a historical process. But it is also, and in a dialectical manner, the starting point of a historical movement in which the labour subsumed to capital interprets the productive, social and political organisation of exploitation and overturns it into the organisation of its own autonomy. ${ }^{50}$

This dialectical approach seems capable of taking culture seriously as political terrain and not a mere effect of the material development. However, it still reduces political composition to the "organisation of autonomy" by the working class, as if all proletarian culture would necessarily be emancipatory in nature. This needs to be revised by addressing ideology as a central part of political composition. Other than proletarian culture, the notion of ideology is able to grasp both the cultural elements that foster working-class autonomy and those hindering it. But first - in line with the classical notion of political composition - we need to address the question of organization of the labor movement.

4.1 Organization. The organization of the workers councils first gained relevance in Bavaria during the peace strikes in January 1918, through pacifists and socialists that were eager for a nationwide peace strike in the armament factories. With this strike, they hoped to hit the backbone of the German wartime economy. ${ }^{51}$ In Bavaria, Sarah Sonja Lerch and Kurt Eisner were the central agitators. They were both founding members of the Socialist Independent Social Democratic Party of Germany(USPD), which had split from the Social Democratic Party of Germany (SPD, thereafter called "Majority Social Democratic Party," MSPD) after it supported the financing of the war. Most armament workers (many of them women) decided to join the strike demanding immediate peace. Hundreds of thousands of workers throughout the German Reich attended the strike. The MSPD and the official trade unions condemned the call for the peace strike. It was, they argued, not a labor dispute, but a political strike and therefore illegal. When they could not prevent the strike, the Bavarian MSPD leadership around their chairman Erhard Auer pointed the police toward the strike leaders. After their arrest, the MSPD took control of the strike and declared it to be over. Those who continued to strike faced severe police and military repression. As one of the central leaders, Lerch died in a Munich prison. Many of the strikers faced punitive drafts into the military. However, the emerging structures of self-organization, revolutionary shop stewards, and first workers' councils remained intact and continued to operate despite the repression. Thus, a first form of class-based revolutionary self- 
organization was created. ${ }^{52}$ At the same time, the January strike and its repression constituted the first major clash between the opposing factions of Social Democrats and revolutionaries in the Bavarian labor movement.

On November 7, 1918, Social Democrats and socialists called for a joint peace demonstration in Munich, in which about sixty thousand people participated. While the MSPD wanted to end the demonstration after calling for reforms, thousands of radicals went on to occupy public buildings. Soldiers ordered to crush the uprising refused to shoot and instead even joined the insurgents. Thereby, in a nonviolent revolution, they overthrew the Wittelsbach monarchy dynasty, which had ruled Bavaria for 738 years. In the same night, they formed official workers' and soldiers' councils, and elected Kurt Eisner as their prime minister for a new socialist government. With this coalition between workers and soldiers and the formation of soldiers' councils, the revolutionary self-organization reached a new level.

When Eisner formed his new government and ministries, however, he also gave central government positions, such as the Ministry of the Interior, to his old enemies from the MSPD. He aimed for a compromise between parliamentarianism and council democracy. However, the MSPD leadership systematically undermined the councils and tried to preserve the old monarchist state apparatus. In this, they used the spatial dispersal of the BCR and the subsequent lack in communication described above. For example, the Ministry of the Interior never sent back answers to questions and complaints from provincial councils to the requesting councils themselves, but instead to the respective magistrates in the traditional way. ${ }^{53}$ From the beginning of the revolution, Auer also prepared for the violent suppression of the council movement. To this end, on Christmas in 1918, together with monarchist military and representatives of the Munich aristocracy, he founded a counter-revolutionary militia. A detailed plan for the occupation of important public buildings was prepared. ${ }^{54}$

The tensions between parliamentarianism and council democracy culminated in the decision to hold parliamentary elections on January 12, 1919, despite the resistance of the council-activists. Anarchists and communists had called to boycott the elections and the MSPD constantly agitated against the Left. Still, the crushing defeat came as a surprise to the Socialists of the USPD: They gained only 2.5 percent of the votes, which meant a shrinkage to three seats in the Landtag (Federal State Parliament). The Left Farmer's Union, another council-friendly party, won only 9 percent of the votes. The winners of the day were the conservative Bavarian People's Party with 35 percent and the MSPD with 33 percent of the votes. The right-wing liberal DDP got 14 percent and the nationalist German People's Party (DNVP) together with the Palatine Central Party received 6 percent. With an 86 percent turnout, the left-wing call to boycott the elections must also be considered a failure. ${ }^{55}$ Thus, the biggest part of the working class, even the revolutionaries, voted for the MSPD despite their anti-revolutionary politics. The high unemployment rates mentioned above were one cause for this, as they had sparked dissatisfaction with the Eisner government among the proletarianized. 
The socialist government immediately took several measures, such as the introduction of the eight-hour day, on November 13, 1918. Additionally, employers were obliged to reintegrate men returning from the war into their old positions. However, the effects of these measures manifested too late (in December 1919, the number of unemployed had dropped to 470,000 again) so that the USPD did not profit from them. ${ }^{56}$ Most of the better off strata in turn had precious little sympathy for the old regime, but felt that it had now been ousted and were quite happy with a moderate democratization entailing a compromise with the progressive sections of the middle class.

Facing the election results, Eisner decided to resign. On the day of the respective session of the Landtag, however, he was assassinated by a far-right anti-Semitic student. At this point, the rift between the MSPD and the Left had already advanced so far that many immediately assumed that Auer was the mastermind behind the assassination. A council-activist stormed into the Landtag building and opened fire on Auer, who was badly wounded and another politician was killed. The prior minister of culture, Johannes Hoffmann, took Auer's place as chair of the Bavarian SPD. After the shootout, the parliamentary politicians fled and did not return. Consequently, the council congress suddenly held power in its own hands.

The councils then tried to negotiate a new government with the MSPD and the USPD. Two opposing groups quickly emerged: one side consisted of the MSPD, the right wing of the USPD, and the majority of the farmers and soldiers councils. This group, which had the majority of delegates on its side, tried to restore a parliamentary government in which it would dominate. On the other side were the radicals, consisting of the delegates of the revolutionary workers' council, the representatives of the unemployed, and those of the demobilized soldiers. On many points the radicals won the support of the left wing of the USPD and a minority of the farmers' councils. ${ }^{57}$ During the negotiations, however, it became public that the Social Democrats were at the same time negotiating a counter-revolutionary coalition with the Right liberal DDP and the conservative Bavarian People's Party (BVP). Thus, the rift between social democracy and the Left became irreversible: Angry council activists with massive demonstrations and threats of a general strike forced the political leaders to proclaim a full Council Republic on April 7, 1919. ${ }^{58}$

From this point on, the BCR was in place, but it always remained contested. A provisional central committee was elected and immediately began to initiate radical changes to the political system (binding regulations for council-democracy, removal of monarchist officers, installation of a revolutionary tribunal); in culture and education (separation of church and state, free university courses and cultural events for workers, reorganization of art and education in councils, a program for anti-authoritarian schooling), and in property relations (redistribution of housing, food, and means of production). ${ }^{59}$ A proclamation read: "The workers council of each company are to elect delegates for the provisional local socialization councils (e.g. the Nuremberg metal workers 
council), whose action committees immediately start the socialization of the means of production together with the central economic committee."60

The MSPD under Hoffmann set up a counter-government with the rightwing parties BVP and DDP in Bamberg (northern Franconia). Together, they reactivated the plan for a coup in Munich on April 13, 1919. Social democracy cooperated with the anti-Semitic Thule Society, which infiltrated councils and passed information to Bamberg. The provisional council government was largely paralyzed by the military coup. Again, it was the workers' and soldiers' councils, which set up revolutionary self-defense, that put down the coup. These men and women later also formed the backbone of the Bavarian Red Army, which at times grew up to ten thousand people. It consisted not only of communists, but also of Social Democrats and Christians. About two thirds of them were industrial workers and one third were farmers. Nine out of ten had previously served in the Imperial Army. Women also joined the Red Army and served as paramedics and spies. In addition, released Russian and Italian prisoners of war volunteered. ${ }^{61}$

As a next step, Hoffmann asked the Reich Military Minister, his party comrade Noske, to send the Reichswehr (German national army) to Bavaria. However, the Reichswehr was largely demobilized after the war and the remaining soldiers were said to be unreliable. Therefore, the Social Democrats formed a counter-revolutionary coalition with the extreme-right paramilitaries of the Freikorps. The most important Freikorps was the Grenzschutz Ost. The commander of this association was Colonel Franz Xafer von Epp, who had already participated in the suppression of the Boxer Rebellion in China and in the genocide of the Nama and Herero in German Southwest Africa. Now, with the support of the Social Democratic Military Minister, he was gathering more and more reactionary militiamen on the Ohrdruf training ground in Thuringia. He found his recruits especially among the peasants and students. ${ }^{62}$ During the advance of the Reichswehr and Freikorps, there were several massacres among the civilian population. Altogether, there were about one thousand people killed. The MSPD counter-government legalized this by giving orders to shoot revolutionaries on the spot. An officer's handbook on combatting "Spartacists" says: "The groups have to carry out their orders violently. Any negotiation with the enemy or with the population is prohibited. Mildness must be interpreted as weakness, good-naturedness as unreliability of the troops." Therefore, whenever possible, the troops were to be allowed to use flame-throwers and other heavy weaponry. At the end, the book sums up: "The harsher the means the faster the success." After the suppression of the Council Republic and over a thousand dead, a commander declared that these guidelines had "fully proven successful."63

Thus, on the level of political composition, the central line of conflict ran not only within the working class but also between the central institutions of the labor movement itself. The rift between the radical class-oriented council movement and the legalist Social Democrats was the prime reason for the defeat of the BCR in May 1919. The question of class stood at the center of this rift. While the council movement put the working class into the center of its politics, the 
Social Democrats began to abandon the idea of being a class party. Erhard Auer, the chair of the Bavarian Social Democrats, explicitly demanded the MSPD to abandon its working-class orientation. Instead, it should move toward the "new middle classes and civil servants as equal members of a community of those who work with their hands and their brains." 64 This marked the beginning of the transition of the MSPD from a class party to a people's party (Volkspartei). ${ }^{65}$ Thus, the MSPD functioned as a bridging party in terms of class: On the one hand, it still constituted the organizational core of the German labor movement. On the other hand, its leadership moved toward the institutionalization of class compromise by collaborating with bourgeois and right wing groups. ${ }^{66}$ Thus, it becomes clear that the political form of the labor movement was far from pre-determined by the technical composition but rather contingent in terms of political events like the assassination of Eisner. The technical composition of the proletarianized in the industries and the military did not only contribute to the notion of the self-managed producer but probably also carried authoritarian potentials with it, which were quite at odds with the rebellious council movement. These authoritarian tendencies are explored in the next section with special regard to anti-Semitism and anti-feminism.

4.2 Ideology. Women played a central role in the counter-revolution, ${ }^{67}$ at least discursively. One of the most effective narratives of the right-wing propaganda was that in the revolutionary cities, women would be "nationalized" and "distributed among the local anarchist club." 68 Other leaflets have it that "rape is the order of the day in the "Council Republic of Munich'."69 This standard right-wing tale of women in need of protection proved to be very successful for mobilizing fighters, especially among the peasantry. In this rhetoric, a special role was assigned to the countess Haila von Westarp, a niece of the highest commander of the counter-revolutionary forces, General von Oven. The countess had been arrested in Munich as a member of the pre-fascist Thule Society for conspiring against the Council Republic. When the counterrevolutionary forces stood at the gates of the city, Red Army fighters executed her, together with nine other persons. In the counter-revolutionary propaganda, she was immediately declared a saint and martyr who was to be avenged bloodily. ${ }^{70}$ In this, she was assigned the role of the pure "white woman," who was the counter-part to the whore-like "red woman" in reactionary propaganda. ${ }^{71}$ The latter role was given to those women who actively took part in the revolution and could therefore not be depicted as damsels in distress. One of them was the young Communist Hilde Kramer. In her trial after the defeat of the BCR, the central argument of the prosecution was her alleged moral decay. On the one hand, she was depicted as "extremely un-womanly in both her appearance and her manner." 72 On the other hand, masses of evidence were presented to prove a promiscuous lifestyle. Kramer's claim in one letter that "in Bavaria free-love is common" was read by the judge with a remark to the courtroom that "this must be why so many non-Bavarians have come here!"73 In this, the counter-revolutionary propaganda follows a pattern in nationalist rhetoric, 
which Nagel describes as consisting mainly in the interconnection of masculinity and nationalism. ${ }^{74}$ However, on the side of the revolution, anti-feminism played an important ideological role as well.

During the war, more than ninety thousand women had been employed in the Bavarian war industry, according to a 1917 census. $^{75}$ At the end of the war, they were successively dismissed in accordance with a corresponding decree of the Reich Demobilization Office. In this, Eisner's policy of fighting (male) unemployment met opposition from feminists who tried to defend women's access to wage labor. The BSF and other feminists formed women's unions to fight against female unemployment. In this, they were also opposed by some of the revolutionary council structures, which were dominated by men. Thus, Toni Sender argued that:

In the worker's councils we find only a very few female representatives who have no relation whatsoever to the number of women workers. Even more so in the executive committees: There only in the rarest of cases a female delegate was to be found. ${ }^{76}$

This underrepresentation of women in the council structures was a widespread phenomenon in the worker's councils all over Germany. It led some liberal feminists like Gertrud Bäumer to argue against granting powers to the councils because, as bodies representing male producers, they competed with the suffrage rights that female consumers had finally secured after the end of the war. ${ }^{77}$ Women in the Bavarian council-movement had to deal with this problem even more acutely. Here, for the first time in German history, they were allowed to vote in the federal elections (Landtagswahl) as of January 1919. At the same time, the council movement saw the election as the attempt to end council democracy in favor of parliamentarianism and therefore called for a boycott. On the other side, the Munich domestic worker's association demanded that the women: "must under no circumstances renounce the right to vote [...] On January 12 and 19, voting is more important than any domestic activity. Housewives who do not vote or do not cast their votes for candidates who represent their own interests are guilty if the future only takes from the housewife and mother and gives nothing., 78 Thus, parliamentarianism granted suffrage to women while their representation in the councils remained unclear. Many feminists therefore voted for antirevolutionary parties. ${ }^{79}$

Moritz Föllmer has argued that "the quest to restore, revive or otherwise strengthen male subjectivities was a major driver behind the protests, strikes and local uprisings," and that the November revolution should be understood as "fragmented into a myriad acts of masculine rebellion and confrontations." 80 Such an interpretation seems overly subjectivist and neglects the central role of women revolutionaries and their successes. However, it is important to underline that class and gender were important political categories in the BCR. At some points, the struggles for worker's power and for women's power overlapped, whereas at other points, they conflicted. Importantly, in the last phase 
of the revolution, there was a veritable anti-feminist backlash among the Left. While previously women had been represented in leading positions in the revolutionary organizations, they were now pushed back again. For example, Eugen Leviné, the chair of the Munich branch of the Communist Party of Germany (KPD) asserted that women were no longer allowed to sign party communiques and were removed from leadership positions. ${ }^{81}$

Thus, anti-feminist ideology within the counter-revolution, as well as within the revolution contributed to the defeat of the BCR by playing a divisive role. The first conflict was about competition between women in wage labor and demobilized soldiers, demanding to be reintegrated into the labor market. Maybe even more important was the question of the relationship between women's suffrage and council democracy. The claim that the counter-revolution was defending the integrity of women deepened that conflict. The second important ideological formation within the Bavarian working class was anti-Semitism.

Many, if not most of the leading revolutionaries were Jews. Among them were: Kurt Eisner and his associates Sarah Sonja Lerch, Felix Fechenbach, and Edgar Jaffé; the central figures of the first Council Republic Ernst Toller, Erich Mühsam, Gustav Landauer, Otto Neurath, and Arnold Wadler; as well as the head of the second Council Republic Eugen Leviné and his comrade Towia Axelrod. All of them, however, were more or less estranged from the Jewish community, the majority of which was against the revolution. This was mainly owed to fears that a "Jewish revolution" would spark anti-Semitic reactions, but also to economic interests. These factors drew many Bavarian Jews toward liberal forces. ${ }^{82}$ It is important nonetheless, to notice that, even if they did not participate in religious practice, many of the Jewish revolutionaries still identified as Jews, mainly as a reaction to the ever-present anti-Semitism. Most of them saw the struggle of Jewish emancipation intimately connected with the struggle against class oppression. The political right used the fact of Jewish participation in the revolution to depict the BCR as a conspiracy of "Jewish aliens." 83 This proved effective, as "anti-Semitism was the common creed on which all nationalist groups, corporations and sects in Munich at the turn of the century could agree." 84

The organizational spearhead of anti-Semitism within the BCR was the Thule Society, a secret league around the esoteric Rudolf Glauer. Its members wanted to fight the swing to the Left in Bavaria, for which they blamed a Jewish conspiracy. Thule's goal was to fight this "conspiracy" with its own conspiratorial means. For this purpose, they aimed to establish a national dictatorship, under which finally all Jews were to be expelled from the German Reich. First, Thule made propaganda its central task. For this purpose, Glauer bought the newspaper Münchner Beobachter with the assets of his wife. Under his editorial office, the tabloid became the central organ of the Thule Society and agitated against Jews and revolutionaries. Glauer decreed the swastika and the bare sword as the symbol and "Heil und Sieg" as the official greeting of the association. ${ }^{85}$ 
The MSPD leadership did not shy away from cooperating with this organization in their counter-revolutionary politics. Thus, Thule's first militant project was nothing less than the failed attempt to kidnap Kurt Eisner and to install Erhard Auer as prime minister. ${ }^{86}$ When the counter-revolutionary forces later invaded Munich, many of them had swastikas painted on their steel helmets to demonstrate their connection to Thule. ${ }^{87}$ On August 4, 1919, Thule was registered as an official association in Munich under the name Thule-Gesellschaft zur Erforschung deutscher Geschichte und Förderung deutscher Art e.V. From then on, they were legally able to pursue their pre-fascist agitation. In this, they were joined by the veterans of the Freikorps, for whom anti-Semitism also was an ideological cornerstone.

As Brenner ${ }^{88}$ and Gerwarth ${ }^{89}$ have shown, during and after the Bavarian revolution, hatred, especially against the so-called Ostjuden ("eastern Jews") from Galicia, was an integral part of mainstream politics and also spread into parts of the Left. Therefore, the central demand of the Thule Society to expel this group from Bavaria found some approval among the Bavarian population. After the defeat of the revolution, the right-wing government under Gustav von Kahr in fact undertook deportations of "eastern Jews" as one of its first actions. Thus, even "before Munich became the capital of the National Socialist movement, it had already become the capital of anti-Semitism in Germany." 90

On December 1, 1919, martial law was revoked in Munich, but Bavaria remained under the government of a military junta for the time being. As the Treaty of Versailles stipulated that the Weimar Republic might only maintain an army of a maximum of one hundred thousand men by the deadline of January 1, 1921, the Freikorps were largely dissolved. However, some of them were taken over into the Reichswehr. This included the Freikorps Epp, which was the bloodiest in the suppression of the Council Republic and killed a large number of civilians and prisoners, like the anarchist philosopher Gustav Landauer. When the rise of Nazism began in Bavaria, Franz Xafer von Epp and his prominent officers Röhm, Hess, Dietl, Frank, and Strasser boasted that the Freikorps Epp had been one of the "birth cells of the movement."91 Thus, the political socialization of a large majority of protagonists of the NS-dictatorship took place in the pre-fascist organizations of the counter-revolution from 1918 to $1920 .^{92}$

After the counter-revolution, many Freikorps units formed so-called Wehrverbände or they joined other fascist paramilitary organizations such as the Stahlhelm or the $S A$. Former Freikorps members were also active in the Einwohnerwehr, which made news with political murders-including Finance Minister Erzberger and Reich Foreign Minister Rathenau. These paramilitary units took part in overthrowing the Social Democratic government under Hoffmann, which had raised them to power them before. In his place, the right-wing monarchist Gustav von Kahr was elected prime minister. The Thule-newspaper Münchner Beobachter was renamed Völkischer Beobachter and became the central organ of the Nazi movement. Hitler later described the anti-Semitism in the counter-revolution as one of the central ideological 
preconditions of Nazism, which his party then transformed into a larger movement. $^{93}$

To conclude, anti-Semitism constituted the ideological hinge between the old monarchist and the new fascist Right. During the revolution, the monarchist Right had largely lost its power, as its central organization, the military, was crushed: After the German defeat in World War I, it had not only lost its material power but also most of its positive reputation among the population. Subsequently, the counter-revolutionary collaboration between the MSPD and the Freikorps contributed to the rebirth of the Right in its fascist form. But also within the council movement, Jews had to struggle with the omnipresence of anti-Semitism. The wide spread of this ideology within the working class and the labor movement can therefore help to explain the smooth transition of Bavaria from Council Republic to the birthplace and center of Nazism. Like anti-feminism, anti-Semitism cannot be neglected in an analysis of the political composition of the Bavarian working class, as it laid the ideological basis for the division and defeat of the BCR.

\section{Conclusions}

By revisiting the German council movement as a central case for the development of the theory of class composition, this article suggests some revisions to the theory. The concept of technical composition is useful to analyze the material basis for the council movement's development. In Bavaria, like in other regions, the council movement was strongest in the industrial centers. Nonetheless, it was not restricted to these. Instead, it involved even smallest provincial towns where workers' and peasants' councils took over power. Later, however, as communication between the provinces and Munich was cut off, many peasants and farmers joined the counter-revolution by blocking food deliveries and joining the Freikorps forces in large numbers. To understand this, it is essential to emphasize space and communication infrastructures as important categories for technical class composition.

The second section of the article introduced the concept of social class composition in order to account for struggles over reproduction and consumption. Due to the war debts, heavy inflation deprived capital of the possibility to use the wage as its central tool for producing workers' consent and obedience. Food prices were rising drastically, causing shortages and famine. At the same time the Spanish flu pandemic struck all warring nations. After the war, many dismissed soldiers and armament workers could not find new positions, giving rise to a wave of unemployment. Subsequently, the unemployed became the militant spearhead of the council movement. Women were affected most by this crises of reproduction, which caused many of them to conjoin feminist and revolutionary causes. However, material misery later also drove many men into the arms of the Freikorps militias who could afford high guerdon.

The third section suggested some revisions to the concept of political class composition. First, it critiqued Bologna's deduction of the councils as form of 
struggle from the technical composition as overly deterministic. Instead, it proposed a dialectical relationship between technical, social, and political composition. Thus, the major conflict of the Bavarian revolution between councils and parliament took place within the labor movement itself. While the technical composition laid the foundation both for the idea of self-management and authoritarianism, the outcome was dependent on contingent political events such as the assassination of Eisner. The third section also emphasized the necessity of a concept of ideology so as to avoid the overly optimistic expectations of proletarian culture necessarily promoting working-class autonomy. Namely, anti-Semitism and anti-feminism played central roles as integrating ideologies of the counter-revolution. They were, however, also present within the revolution itself, leading to frictions damaging the alliances between different struggles for emancipation. An understanding of the wide spread of anti-Semitism in the Bavarian labor movement is also necessary to understand the smooth transition of Bavaria from Council Republic to the center of Nazism.

A de-centered analysis of the Bavarian Council republic can serve as an important point of reference for understanding the making and defeat of the revolution. The protagonists of the revolution were proletarianized by the politico-economic conditions they found themselves in, but still remained a heterogeneous multitude. This heterogeneity in turn is not to be understood as a subjective lack of class-consciousness, but as an objective diversity in conditions of domination. The joining together of the different struggles for emancipation contributed strongly to the labor movement reaching a climax of political power that went further in Bavaria than in all other parts of Germany. Even if the revolution was ultimately defeated, it could permanently win parliamentary democracy, labor rights like the eight-hour day, and fundamental women's rights.

\section{NOTES}

* The author wishes to thank Janika Kuge and Günther Gerstenberg for important comments and support and two anonymous reviewers for their valuable feedback.

1. The most widespread term is "Bavarian Soviet Republic." As "soviet" is the Russian word for council, this term is literally correct but misleading as it implies that the Bavarian model of council-government simply copied the Russian one, which it did not. I will therefore stick to "Council Republic." See also: Gabriel Kuhn (ed.), All Power to the Councils! A Documentary History of the German Revolution of 1918-1919 (Oakland, 2012), 205.

2. While the Council Republic was the official state form for some weeks, this is not to imply any monolithic bloc. There were many frictions and contradictions within the council movement. The most important was the shift in power from a libertarian socialist central council to another one dominated by the Communist party after a failed Social Democratic coup.

3. Tankred Dorst (ed.), Die Münchner Räterepublik - Zeugnisse und Kommentar (Frankfurt a.M., 1983); Gerhard Schmolze, Revolution Und Räterepublik München 1918/19 in Augenzeugenberichten. (München, 1978).

4. Michael Seligmann, Aufstand der Räte. Die erste bayerische Räterepublik vom 7. April 1919 (Grafenau, 1999).

5. Dania Alasti, Frauen der Novemberrevolution: Kontinuitäten des Vergessens (Münster, 2018); Eliza Johnson, "The 'Revolutionary Girl with the Titus-Head': Women's Participation in the 1919 Revolutions in Budapest and Munich in the Eyes of Their Contemporaries," 
Nationalities Papers 28 (2000): 541-50. doi:10.1080/713687483; Christiane Sternsdorf-Hauck, Brotmarken und rote Fahnen. Frauen in der bayrischen Revolution und Räterepublik 1918/19 (Frankfurt a.M, 1989).

6. Such an approach is not to be confused with overly generalized or deterministic stances, which have rightly been criticized: e.g., Michæl André Bernstein, Foregone Conclusions (Berkeley, CA: 1994).

7. Steve Wright, Storming Heaven: Class Composition and Struggle in Italian Autonomist Marxism (London, 2002).

8. Sergio Bologna, "Class Composition and the Theory of the Party at the Origin of the Workers-Council Movement," Telos 13 (1972): 4-27. doi:10.3817/0972013004.

9. The comparative method of the "historical revisit," in which the object of historical studies is re-assessed, was developed in Michael Burawoy, The Extended Case Method - Four Countries, Four Decades, Four Great Transformations, and One Theoretical Tradition (Berkeley, CA, 2009).

10. "The Workers' Inquiry and Social Composition. A New Framework for Class Composition Analysis," Notes from Below 1 (2018). https://notesfrombelow.org/article/ workers-inquiry-and-social-composition.

11. Terry Radtke, "Proletarianization: Past and Present," International Labor and Working-Class History 24 (1983): 81-3. https://doi.org/10.1017/S014754790000822X.

12. Martin H. Geyer, Verkehrte Welt: Revolution, Inflation und Moderne, München 19141924 (Göttingen, 1998).

13. Volker Weidermann, Träumer - Als die Dichter die Macht übernahmen (Köln, 2017).

14. E.g., leaflet, April 1919, Monacensia Archive, F.Mon. 330.

15. Helmut Braun, "Wirtschaft (Weimarer Republik)," in Historisches Lexikon Bayerns (2007). https://www.historisches-lexikon-bayerns.de/Lexikon/Wirtschaft_(Weimarer_Republik).

16. Statistisches Landesamt, Statistisches Jahrbuch Für Den Freistaat Bayern 14 (München, 1919), 209-10.

17. Bologna, "Class Composition," 6.

18. Robert Gerwarth, Die Besiegten: Das blutige Erbe des Ersten Weltkriegs, (München, 2017); Thomas Weber, Hitler's First War: Adolf Hitler, the Men of the List Regiment, and the First World War (Oxford, 2010).

19. Bologna, "Class Composition," 6.

20. Martin Comack, Wild Socialism: Workers Councils in Revolutionary Berlin, 1918-21 (Lanham, 2012); e.g., Klaus Weinhauer, Anthony McElligott, and Kirsten Heinsohn (eds.), Germany 1916-23: A Revolution in Context (Bielefeld, 2015).

21. Thomas Klikauer, "Germany's Revolutionary Workers of 1918-1919," Critique 43 (2015): 563. doi:10.1080/03017605.2015.1099852.

22. Schmolze, Revolution Und Räterepublik.; e.g., Dorst, Münchner Räterepublik.

23. Seligmann, Aufstand der Räte.

24. Simon Schaupp, Der kurze Frühling der Räterepublik: Ein Tagebuch der bayerischen Revolution, (Münster, 2018).

25. Braun, "Wirtschaft (Weimarer Republik)."

26. Wilhelm Mattes, Die bayerischen Bauernräte: eine soziologische und historische Untersuchung über bäuerliche Politik (Stuttgart, 1921).

27. Schaupp, Der kurze Frühling der Räterepublik.

28. Doreen Massey, For Space (London, 2005).

29. Notes from Below, "The Workers' Inquiry."

30. This can be formalized as C(LP)-M-C(MoS, LP) whereas from the perspective of capital, the production of surplus value is expressed in the formula M-C-M' (money-commodity-more money). See: Karl Marx, Das Kapital, Band 1, MEW 23, (Berlin, 1977), 161-70.

31. Notes from Below, "The Workers' Inquiry."

32. Gerald D. Feldman, The Great Disorder: Politics, Economics and Society in the German Inflation, 1914-24 (New York, 1993).

33. Karl-Ludwig Ay, Die Entstehung einer Revolution.: Die Volksstimmung in Bayern während des Ersten Weltkrieges, (Berlin, 1968).

34. Ralf Höller, Der Anfang, der ein Ende war (Berlin, 1999), 18.

35. Marc Hieronimus, Krankheit und Tod 1918: zum Umgang mit der Spanischen Grippe in Frankreich, England und in dem Deutschen Reich (Münster, 2006); David Killingray and 
Howard Phillips (eds.), The Spanish Influenza Pandemic of 1918-19: New Perspectives (London and New York, 2003).

36. Braun, "Wirtschaft (Weimarer Republik)."

37. Ibid.

38. Günther Gerstenberg, Der kurze Traum vom Frieden: Ein Beitrag zur Vorgeschichte des Umsturzes in München 1918 mit einem Exkurs über Sarah Sonja Lerch in Gießen von Cornelia Naumann (Bodenburg, 2018); Schaupp, Der kurze Frühling der Räterepublik.

39. Oliver Haller, "German Defeat in World War I, Influenza and Postwar Memory," in Germany 1916-23: A Revolution in Context, ed. Klaus Weinhauer, Anthony McElligott, and Kirsten Heinsohn (Bielefeld, 2015), 151-80.

40. Erich Wollenberg, Als Rotarmist Vor München (Hamburg, 1929), 95.

41. Gerstenberg, Der kurze Traum vom Frieden.

42. Sternsdorf-Hauck, Brotmarken und rote Fahnen, 13.

43. Schaupp, Der kurze Frühling der Räterepublik, 93.

44. Kathleen Canning, "Das Geschlecht Der Revolution - Stimmrecht Und Staatsbürgertum 1918/19," in Die Vergessene Revolution von 1918/19, ed. Alexander Gallus (Bonn, 2010), 84-116.

45. Sternsdorf-Hauck, Brotmarken und rote Fahnen., 33.

46. Toni Sender, "Die Frauen Und Das Rätesystem," in Alle Macht Den Räten. Rätemacht in Der Diskussion.(ed.), Theo Panther (Münster, 1919), 398.

47. Ibid., 403.

48. Salar Mohandesi, "Class Consciousness or Class Composition?" Science \& Society 77

(2012): 72-97. doi:10.1521/siso.2013.77.1.72.

49. Notes from Below, "The Workers' Inquiry."

50. Bologna, cited in: Wright, Storming Heaven, 187.

51. Chaja Boebel and Lothar Wentzel (eds.), Streiken gegen den Krieg: Die Bedeutung der Massenstreiks in der Metallindustrie vom Januar 1918 (Hamburg, 2015).

52. Gerstenberg, Der kurze Traum vom Frieden.

53. Schaupp, Der kurze Frühling der Räterepublik, 72.

54. Richard Dove, He Was a German: Biography of Ernst Toller (London, 1990).

55. Schaupp, Der kurze Frühling der Räterepublik, 107.

56. Stephanie Neuner, "Demobilmachung, 1918-1923 (Ökonomisch, Gesellschaftlich, Kulturell)," in Historisches Lexikon Bayerns, (2006). https://www.historisches-lexikon-bayerns. de/Lexikon/Demobilmachung,_1918-1923_(\%C3\%B6konomisch,_gesellschaftlich,_kulturell)

\#Arbeitsmarkt_und_Arbeitslosigkeit.

57. Schaupp, Der kurze Frühling der Räterepublik, 122-25.

58. Seligmann, Aufstand der Räte.

59. Georg Köglmeier, Die zentralen Rätegremien in Bayern 1918/19: Legitimation Organisation - Funktion (München, 2002).

60. Generalvollmacht, April 1919, Monacensia Archive Munich, F.Mon. 2659.

61. Wollenberg, Als Rotarmist Vor München.

62. Schaupp, Der kurze Frühling der Räterepublik.

63. Mark Jones, Am Anfang war Gewalt: Die deutsche Revolution 1918/19 und der Beginn der Weimarer Republik (Berlin, 2017), 304-5.

64. Stefan Berger, Social Democracy and the Working Class in Nineteenth-and TwentiethCentury Germany (London and New York, 2014), 98. doi:10.4324/9781315841403.

65. Rüdiger Hachtmann, "Blick zurück und in die Zukunft. Die Sicht auf die 'Novemberrevolution' 1919 bis 2018 und mögliche Perspektiven einer kritischen Revolutionshistoriographie," Sozial.Geschichte Online 23 (September 2018): 128. doi:10.17185/duepublico/47046.

66. Ibid., 115.

67. For a thorough reconstruction of the counter-revolution see: Eliza Ablovatski, "Cleansing the Red Nest": Counterrevolution and White Terror in Munich and Budapest, 1919 (New York, 2004).

68. Leaflet 1.2.1919, Monacensia Archive, F.Mon. 2650.

69. Leaflet, April 1919, Monacensia Archive, F.Mon. 330.

70. Mark Jones, Founding Weimar: Violence and the German Revolution of 1918-1919 (Cambridge, 2018).

71. Klaus Theweleit, Männerphantasien (Berlin, 2019). 
72. Eliza Johnson, "'The revolutionary Girl with the Titus-Head': Women's Participation in the 1919 Revolutions in Budapest and Munich in the Eyes of Their Contemporaries," Nationalities Papers 28 (2000): 547. doi:10.1080/713687483.

73. Ibid., 544.

74. Joane Nagel, "Masculinity and Nationalism: Gender and Sexuality in the Making of Nations," Ethnic and Racial Studies 21 (1998): 242-69. doi:10.1080/014198798330007.

75. Statistisches Landesamt, Statistisches Jahrbuch Für Den Freistaat Bayern 15 (München, 1921), 112.

76. Sender, "Die Frauen Und Das Rätesystem," 397.

77. Canning, "Das Geschlecht Der Revolution."

78. Leaflet, 12.1.1919, Münchner Hausfrauen-Vereinigung.

79. Schaupp, Der kurze Frühling der Räterepublik, 104.

80. Moritz Föllmer, "The Unscripted Revolution: Male Subjectivities in Germany, 19181919," Past \& Present 240 (2018): 169, 176. doi:10.1093/pastj/gty010.

81. Schaupp, Der kurze Frühling der Räterepublik, 145.

82. Michael Brenner, Der lange Schatten der Revolution: Juden und Antisemiten in Hitlers München 1918 bis 1923 (Berlin, 2019).

83. Leaflet, April 1, 1919, Bayerisches Hauptsaatsarchiv, Flslg. 977.

84. Brenner, Der lange Schatten der Revolution, 34.

85. Hermann Gilbhard, Die Thule-Gesellschaft: Vom okkulten Mummenschanz zum Hakenkreuz (München, 2015).

86. Schaupp, Der kurze Frühling der Räterepublik, 87-8.

87. Jones, Am Anfang war Gewalt.

88. Brenner, Der lange Schatten der Revolution.

89. Gerwarth, Die Besiegten.

90. Brenner, Der lange Schatten der Revolution, 38.

91. Schaupp, Der kurze Frühling der Räterepublik, 269.

92. Michael Wildt, Generation des Unbedingten. Das Führungskorps des Reichssicherheitshauptamtes. Studienausgabe, (Hamburg, 2003).

93. Adolf Hitler, Mein Kampf (New York, 1941), 825. 